\title{
REPRODUCTIVE ASPECTS OF MARINE CLADOCERANS Penilia avirostris AND Pseudevadne tergestina (CRUSTACEA, BRANCHIOPODA) IN THE OUTER PART OF GUANABARA BAY, BRAZIL
}

\author{
MARAZZO, A. and VALENTIN, J. L. \\ Laboratório de Zooplâncton, Departamento de Biologia Marinha, Instituto de Biologia, Universidade Federal do \\ Rio de Janeiro, CEP 21949-900, Rio de Janeiro, RJ, Brazil \\ Correspondence to: Andrea Marazzo, Laboratório de Zooplâncton, Departamento de Biologia Marinha, \\ Instituto de Biologia, Universidade Federal do Rio de Janeiro, CEP 21949-900, \\ Rio de Janeiro, RJ, Brazil, e-mail: marazzo@biologia.ufrj.br \\ Received June 19, 2002 - Accepted June 9, 2003 - Distributed August 31, 2004
}

(With 3 figures)

\begin{abstract}
The objective of this study was to report on some aspects of marine cladoceran reproduction in Guanabara Bay. Samples were collected during 1985 using a conical net with $200 \mu \mathrm{m}$ mesh. Two species were identified: Penilia avirostris and Pseudevadne tergestina. Both species disappeared from the plankton in winter. Two months before this phenomenon, parthenogenetic females displayed reduction in brood size, while gamogenetic individuals appeared among the populations. This sequence of events is generally typical of marine cladoceran populations in temperate waters.
\end{abstract}

Key words: marine cladocerans, Penilia avirostris, Pseudevadne tergestina, Guanabara Bay, Brazil.

\section{RESUMO}

\section{Aspectos da reprodução dos cladoceros marinos Penillia avirostris e Peseudevadne tergestina (Crustácea, Branchiopoda) na entrada da Baía de Guanabara, Brasil}

O objetivo do presente estudo foi registrar alguns aspectos da reprodução das espécies de cladóceros marinhos que ocorrem na Baía de Guanabara. As amostras foram obtidas durante o ano de 1985, com o auxílio de uma rede cônica de $200 \mu \mathrm{m}$ de diâmetro de poro. As duas espécies identificadas (Penilia avirostris e Pseudevadne tergestina) são comuns à baía, mas desaparecem do plâncton no inverno. Dois meses antes desse fenômeno, as fêmeas partenogenéticas apresentam redução no tamanho da ninhada, enquanto os animais gametogenéticos surgem na população. Essa seqüência de eventos, em geral, é típica para as populações de cladóceros marinhos que ocorrem em regiões temperadas.

Palavras-chave: cladóceros marinhos, Penilia avirostris, Pseudevadne tergestina, Baía de Guanabara, Brasil.

\section{INTRODUCTION}

Most marine cladocerans are restricted to coastal waters, where they make up a significant part of the zooplanktonic community at given periods. This confers on these animals a major trophodynamic role, as they can be an important food item for carnivorous zooplankton, as well as pelagic fish and their larvae (e.g., Cheng \& Chao,
1982). Despite their high densities, marine cladocerans may disappear from the plankton during certain seasons of the year, which in temperate regions is generally in winter (e.g., Onbé, 1974, 1978a, 1985; Ramirez \& Perez Seijas, 1985).

Cladocerans present two forms of reproduction: parthenogenesis and gamogenesis. Throughout most of the year only females occur, reproducing themselves by parthenogenesis and giving birth to new females. 
The explosive increase in their densities is the result of the high reproductive potential in parthenogenetic generation. At given periods, when environmental conditions become unfavorable, these females produceboth males and females. Following copulation and fertilization, the female generally produces a single large egg, called a "resting egg", with a resistant external membrane. The animal developing from this egg is always a female, thus restarting the parthenogenetic cycle (Barth, 1972).

According to Nogueira et al. (1988), marine cladocerans (Penilia and Pseudevadne genera) in Guanabara Bay suffer wide-ranging seasonal density variations. Based on these initial observations, the present study aims at describing the transition from parthenogenetic to gamogenetic reproduction of the species found in this region.

\section{METHOD}

Guanabara Bay is located in Rio de Janeiro, southeast Brazil $\left(22^{\circ} 41^{\prime}-22^{\circ} 56^{\prime} \mathrm{S}\right.$ and $43^{\circ} 02^{\prime}$ $43^{\circ} 18^{\prime} \mathrm{W}$ ). This bay has been classified as a coastal estuary with shallow and partially mixed waters (Amador, 1982). The climate is tropical humid with a rainy season occurring in summer (DecemberMarch) (IBGE, 1977).

From January to December 1985, in the morning (7:00-11:00)at all 5 stations (Fig. 1) sample collections were carried out, as well as temperature and salinity data recorded. Zooplankton samples were obtained during horizontal surface hauls using a $0.5 \mathrm{~m}$ diameter and $2 \mathrm{~m}$ long conical net ( $200 \mu \mathrm{m}$ mesh) provided with a flowmeter. Samples were preserved in $4 \%$ formaldehyde according to Griffiths et al. (1976). In the laboratory cladocerans were counted and, when samples were large, subsamples were taken with a Folsom plankton splitter (McEwen et al., 1954). At least 100 individuals were counted (Frontier, 1981). Identification of species was carried out under a stereomicroscope following descriptions given by Della Croce (1974) and Ramirez (1981). Immediately following qualitative and quantitative analysis at least thirty animals were randomly taken from each sample (when in sufficient number) and placed in glycerine droplets for body clearing. After 24 hours, the individuals were analyzed under an optical microscope for measurement of body length, sex, brood size (number of embryos per female), and embryo development. For Pseudevadne, length was taken as the distance between the anterior margin of the head and the tip of the body shell. However, Bainbridge (1958) found this distance to vary according to the developmental stages of embryos in this genus, therebye precluding its use as a standard. For Penilia, length was considered as being the distance between the anterior border of the head and the posterior margin of the body-shell dorsal articulation line. Measurements were made with a micrometer eyepiece to the nearest $10 \mu \mathrm{m}$.

Sex was determined according to the descriptions given by Della Croce (1974) and Onbé (1978b). Individuals observed were classified as parthenogenetic (females bearing parthenogenetic embryos) and gamogenetic (females bearing males and resting eggs).

The females' brood pouches were carefully dissected with a fine needle in order to determine the stage of parthenogenetic embryo development. Classification followed the descriptions given by Della Croce \& Bettanin (1965) and Onbé (1974, 1977, 1978a). Premature and mature embryos were separately considered in this study. For Penilia, embryos in stages XI-XII were considered mature, whereas those in all other stages were considered premature (Della Croce \& Bettanin, 1965). For Pseudevadne, embryos in stages I-II were classified as premature, whereas those in stages III-IV were considered mature (Onbé, 1974, 1977, 1978a).

\section{RESULTS}

Mean monthly values for surface water salinity varied from 24.7 to 35.6 (Fig. 2). The lower values recorded from January to March (summer) reflected the seasonally high precipitation levels typical of this region. Temperatures were characteristic of the two well-defined seasons: mean values varied from $21.2^{\circ} \mathrm{C}$ in July (winter) to $28.5^{\circ} \mathrm{C}$ in February (summer) (Fig. 2).

Only two species of marine cladocerans were registered: Penilia avirostris Dana and Pseudevadne tergestina (Claus). Mean annual densities attained 975 ind. $\mathrm{m}^{-3}$ for $P$. avirostris, and 1,204 ind. $\mathrm{m}^{-3}$ for $P$. tergestina, with higher values registered in more external stations (1, 2, and 3. See Table 1). Both species disappeared from the plankton in winter (Fig. 3 ). Populations had consisted mainly of parthenogenetic females. Gamogenetic individuals were observed only two months prior to the disappearance of planktonic populations (Table 1). 
TABLE 1

Mean values of parthenogenetic cladoceran density (ind. $\mathrm{m}^{-3}$ ), and percentage of gamogenetic animals from monthly means. Samples were obtained in 5 stations from January to December 1985 in Guanabara Bay.

\begin{tabular}{|c|c|c|c|c|c|c|c|c|}
\hline \multirow{3}{*}{ Months } & \multicolumn{8}{|c|}{ Penilia avirostris } \\
\hline & \multirow{2}{*}{$\begin{array}{c}\text { Station } \\
1\end{array}$} & \multirow{2}{*}{$\begin{array}{c}\text { Station } \\
2\end{array}$} & \multirow{2}{*}{$\begin{array}{c}\text { Station } \\
\mathbf{3}\end{array}$} & \multirow{2}{*}{$\begin{array}{c}\text { Station } \\
4\end{array}$} & \multirow{2}{*}{$\begin{array}{c}\text { Station } \\
5\end{array}$} & \multirow{2}{*}{$\begin{array}{c}\text { Mean } \pm \\
\text { SD }\end{array}$} & \multicolumn{2}{|c|}{$\begin{array}{l}\text { \% gamogen. } \\
\text { ind. }\end{array}$} \\
\hline & & & & & & & Females & Males \\
\hline Jan & 44.41 & 25.79 & $*$ & 691.05 & $*$ & $253.75 \pm 309.31$ & 0.00 & 0.00 \\
\hline Feb & 1.98 & * & 1.03 & 3.85 & 2.43 & $2.32 \pm 1.02$ & 0.00 & 0.00 \\
\hline Mar & 898.84 & 1383.76 & 1519.46 & $*$ & 95.96 & $974.51 \pm 557.23$ & 24.90 & 11.61 \\
\hline Apr & 378.72 & 379.09 & 181.57 & 179.04 & 11.66 & $226.02 \pm 139.20$ & 0.00 & 5.00 \\
\hline May & 0.00 & 0.00 & 0.00 & 0.00 & 0.00 & $0.00 \pm 0.00$ & - & - \\
\hline Jun & 0.00 & 0.00 & 0.00 & 0.00 & $*$ & $0.00 \pm 0.00$ & - & - \\
\hline Jul & 0.00 & 0.00 & 0.00 & 0.00 & 0.00 & $0.00 \pm 0.00$ & - & - \\
\hline Aug & 0.00 & 0.00 & 0.00 & 0.00 & 0.00 & $0.00 \pm 0.00$ & - & - \\
\hline Sep & 21.08 & 12.08 & 1.40 & 0.00 & 0.00 & $6.91 \pm 8.41$ & 0.00 & 0.00 \\
\hline Oct & * & 17.23 & 71.76 & 1.60 & 0.36 & $22.74 \pm 29.07$ & 0.00 & 0.00 \\
\hline Nov & 11.25 & 6.33 & 13.84 & 0.00 & 0.21 & $6.33 \pm 5.62$ & 0.00 & 0.00 \\
\hline \multirow[t]{2}{*}{ Dec } & 41.81 & 31.89 & 20.37 & 19.78 & 22.67 & $27.30 \pm 8.46$ & 0.00 & 0.00 \\
\hline & \multicolumn{8}{|c|}{ Pseudevadne tergestina } \\
\hline \multirow[t]{2}{*}{ Months } & \multirow{2}{*}{$\begin{array}{c}\text { Station } \\
1\end{array}$} & \multirow{2}{*}{$\begin{array}{c}\text { Station } \\
2\end{array}$} & \multirow{2}{*}{$\begin{array}{c}\text { Station } \\
3\end{array}$} & \multirow{2}{*}{$\begin{array}{c}\text { Station } \\
4\end{array}$} & \multirow{2}{*}{$\begin{array}{c}\text { Station } \\
5\end{array}$} & \multirow{2}{*}{$\begin{array}{c}\text { Mean } \pm \\
\text { SD }\end{array}$} & \multicolumn{2}{|c|}{$\begin{array}{l}\text { \% gamogen. } \\
\text { ind. }\end{array}$} \\
\hline & & & & & & & Females & Males \\
\hline Jan & 7.38 & 4.28 & $*$ & 115.14 & $*$ & $42.27 \pm 51.54$ & 0.00 & 0.00 \\
\hline Feb & 0.61 & $*$ & 3.13 & 11.60 & 7.16 & $5.63 \pm 4.17$ & 0.00 & 0.00 \\
\hline Mar & 149.79 & 230.61 & 253.24 & * & 15.96 & $162.40 \pm 92.88$ & 0.00 & 0.00 \\
\hline Apr & 498.29 & 498.82 & 238.94 & 235.59 & 15.31 & $297.38 \pm 183.16$ & 0.00 & 0.00 \\
\hline May & 1.00 & 0.00 & 829.95 & 4.77 & 2.02 & $167.55 \pm 331.20$ & 0.00 & 0.00 \\
\hline Jun & 0.45 & 0.94 & 0.06 & 0.04 & * & $0.37 \pm 0.38$ & 8.10 & 0.00 \\
\hline Jul & 0.75 & 1.24 & 0.34 & 0.09 & 0.00 & $0.48 \pm 0.46$ & 18.75 & 4.16 \\
\hline Aug & 0.00 & 0.00 & 0.00 & 0.00 & 0.00 & $0.00 \pm 0.00$ & - & - \\
\hline Sep & 0.00 & 0.00 & 0.00 & 0.00 & 0.00 & $0.00 \pm 0.00$ & - & - \\
\hline Oct & * & 612.77 & 652.94 & 6.23 & 52.64 & $331.15 \pm 302.49$ & 0.00 & 0.00 \\
\hline Nov & 4382.98 & 367.45 & 329.73 & 781.01 & 158.50 & $1203.93 \pm 1602.6$ & 0.00 & 0.00 \\
\hline Dec & 34.40 & 51.21 & 23.12 & 19.70 & 8.74 & $27.43 \pm 14.43$ & 0.00 & 0.00 \\
\hline
\end{tabular}

Parthenogenetic female body length varied from 417.6 to $1,012.2 \mu \mathrm{m}$ for $P$. avirostris (annual average: $719.37 \mu \mathrm{m})$, and $392.89-897.36 \mu \mathrm{m}$ for $P$. tergestina (annual average: $574.10 \mu \mathrm{m}$ ) (Table 2). Mean values (from 30 females per sample) of parthenogenetic brood size of P. tergestina varied between 1-14 (average: 6.49), with most females bearing 4-8 embryos (Table 2). P. avirostris presented 1-11 embryos (average: 4.35), most females bearing 36 embryos (Table 2). A noticeable decrease in mean values was registered in March for P. avirostris and in June/July for $P$. tergestina (Fig. 3). Mean number 
of embryos was similar for females bearing premature and mature embryos (Table 2). An analysis between the mother's body length and the number of embryos showed a significant positive linear correlation ( $\mathrm{p}<$ $0.05)$ for $P$. tergestina $(\mathrm{n}=732, \mathrm{r}=0.13)$ but not for $P$. avirostris $(\mathrm{n}=558, \mathrm{r}=0.002)$.

\section{DISCUSSION}

The seasonal distribution, size, and fecundity variations of the marine cladocerans Penilia avirostris and Pseudevadne tergestina were studied in Guanabara Bay. The sequence of events which took place in plankton of the bay is generally typical of marine cladoceran populations: concomitant with the reduction of female size in $P$. avirostris and $P$. tergestina, males appeared in the populations, females displayed less fecundity at the same time that they started to produce resting eggs, and the organisms disappeared from the plankton. This fact reinforces the reproductive standard described by several authors, who have observed that the first gamogenetic individuals of marine cladoceran species appear usually at the population maxima, and sexual reproduction becomes most intense when the population is about to disappear from the planktonic communities (e.g., Gieskes, 1971; Specchi et al., 1974; Onbé, 1974, 1977, 1978a; Rocha, 1982).

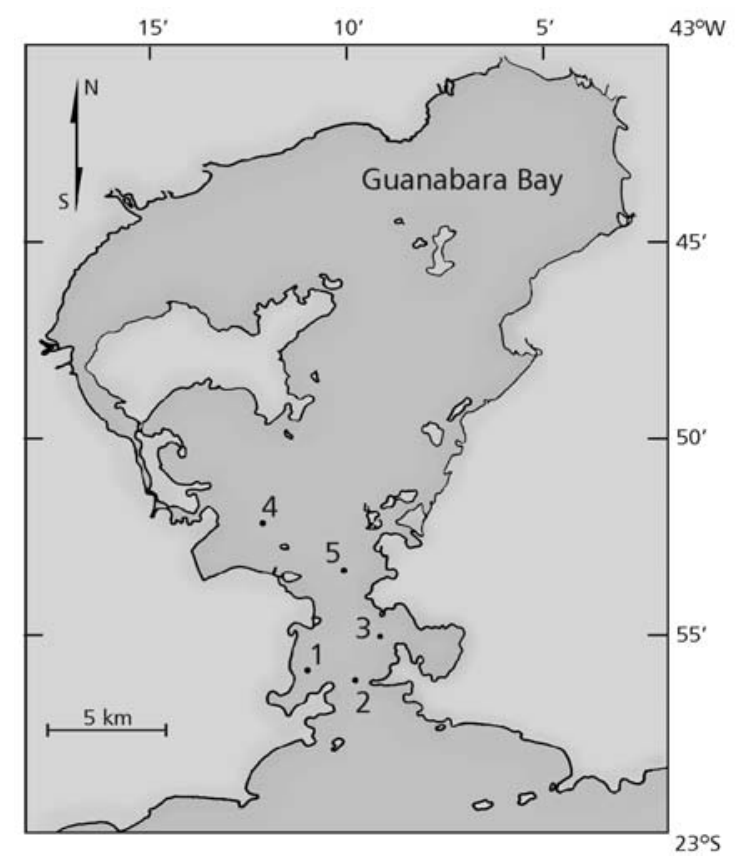

Fig. 1 - Location of the sampling stations in Guanabara Bay.
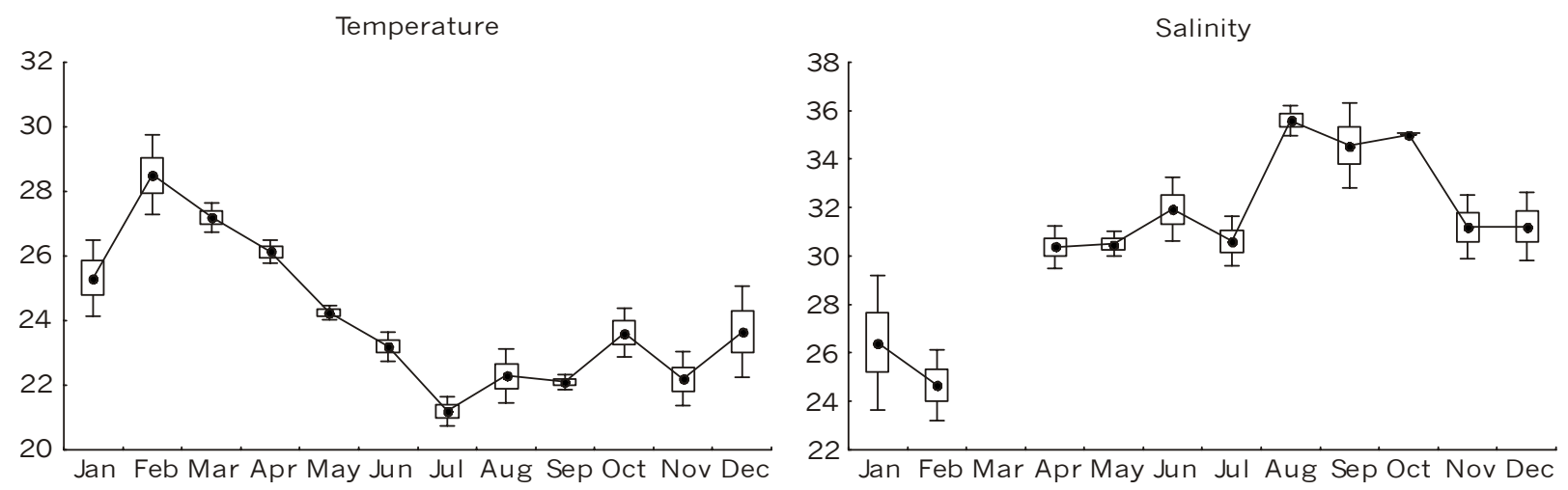

Fig. 2 - Variation of surface water temperature $\left({ }^{\circ} \mathrm{C}\right)$ and salinity from January to December 1985 in Guanabara Bay. The missing line represents absent data. The data were obtained at 5 stations. Point $=$ mean; box $=$ standard error; whisker $=$ standard deviation. 

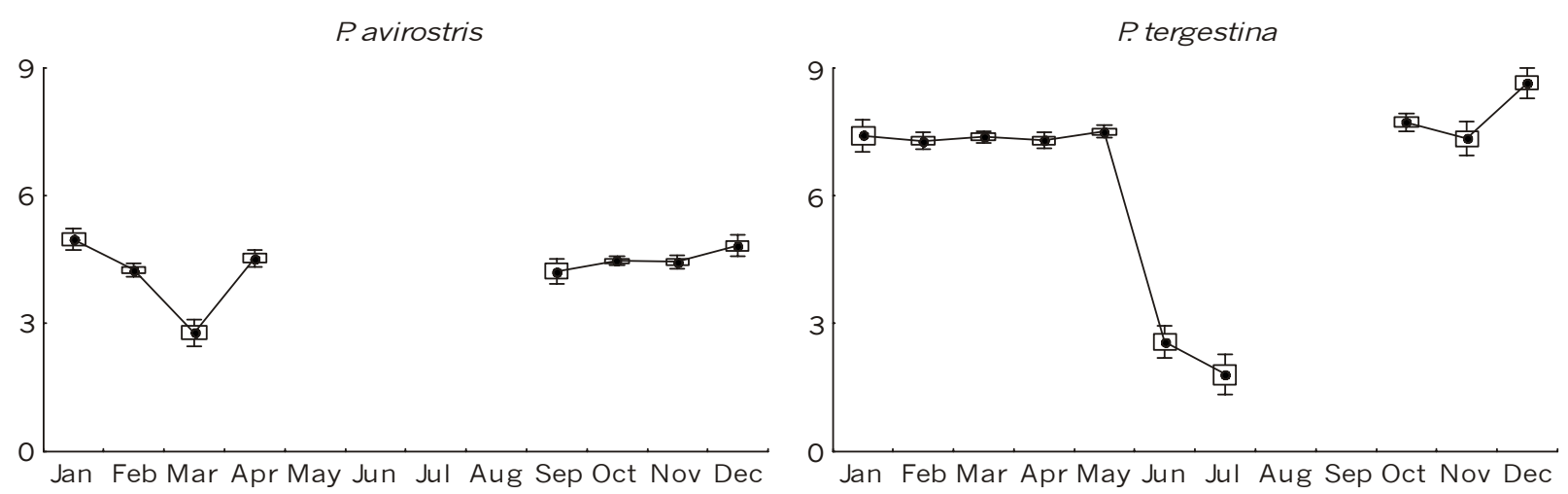

Fig. 3 - Variations in brood size of Penilia avirostris and Pseudevadne tergestina. The data were obtained at 5 stations from January to December 1985 in Guanabara Bay. The missing line represents absent data. Point = mean; box = standard error; whisker $=$ standard deviation.

The seasonal pattern just described may be explained by Berg's theory (1931): after long study of the transition from parthenogenetic to gamogenetic reproduction in Daphnia populations, Berg formulated the hypothesis that the change in reproductive mode reflects unfavorable external conditions and that the main determining factors are temperature, food supply levels, populational density, chemical agents, and excretion products. According to this hypothesis, the variation in these factors (either isolated or combined) creates a state of "depression" in parthenogenetic females resulting in a reduction in average body length and the production of parthenogenetic embryos. The parthenogenetic eggs, which had previously produced only parthenogenetic females, now also produce males. Sexual reproduction results in the formation of resting eggs, which weather adverse conditions in the sediment. For copepods, resting eggs are generally viewed as the result of a mechanism to ensure survival during periods of environmental adversity, with photoperiod, temperature, and fish predation acting as independent cues signalling deteriorating of environmental conditions (Marcus, 1996).

On February 12, extreme temperature and salinity were recorded for Guanabara Bay. Samples taken 21 days later (March 5) evidenced depressed P. avirostris populations. Possibly temperature and salinity were directly or indirectly responsible for depressed conditions in the populations of this species but, on this point, the results of this study can offer no certainty. However, so far an apparent consensus seems to prevail among researchers that temperature variations are conditioning factors in reproductive changes found in marine cladocerans in temperate regions. This is because these organisms are very evenly distributed from spring to autumn. But with the start of winter, depressive features are in evidence and, shortly thereafter, the species disappear from the plankton. Undoubtedly, determining the factors depressing for marine cladocerans is of extreme relevance, as these organisms display significant reproductive changes in in response to a number of environmental conditions and, thus, these changes may become effective ecological indicators, as has been proposed by Gieskes (1971).

In this study, the mean number of embryos was similar for $P$. avirostris and $P$. tergestina females bearing premature and mature embryos. A few authors (see Platt \& Yamamura, 1986) have suggested that certain species of marine cladocerans may partially reabsorb their brood when embryos are still in initial developmental stages. For example, Bainbridge (1958) observed several disintegrated embryos and indistinct tissue spots in the brood pouch of some E. nordmanni females. Ramirez \& Perez Seijas (1985) found that, for $P$. intermedius and E. nordmanni, embryos in initial developmental stages were always more numerous when compared to mature embryos in the female's brood pouch. The results of the present study eliminate the hypothesis that $P$. avirostris and $P$. tergestina reabsorb part of their broods in the beginning stage of development.

Acknowledgements - This research is part of a PRONEX project, and was supported by the Coordenadoria de Aperfeiçoamento de Pessoal de Ensino Superior (CAPES), Conselho Nacional de Desenvolvimento Científico e Tecnológico (CNPq) and the Fundação de Amparo à Pesquisa do Estado do Rio de Janeiro (FAPERJ). 
TABLE 2

Variation in embryo number (premature and mature embryo separately considered) per parthenogenetic female of Penilia avirostris and Pseudevadne tergestina from January to December in Guanabara Bay. Female sizes were grouped by classes.

\begin{tabular}{|c|c|c|c|c|c|c|c|c|c|c|c|c|c|c|c|}
\hline $\begin{array}{l}P \text {. avirostris } \\
\text { bodv lenoth }\end{array}$ & \multicolumn{14}{|c|}{ Embryo number } & \\
\hline $\begin{array}{c}\ldots \text { with premature } \\
\text { embryos }\end{array}$ & 1 & 2 & 3 & 4 & 5 & 6 & 7 & 8 & 9 & 1 & 01 & & 2 & 131 & \multirow{6}{*}{$\begin{array}{c}\text { Females with embryos }=390 \\
\text { Mean number of } \\
\text { embryos }=5.25\end{array}$} \\
\hline $417.00-516.99$ & & & & & 4 & & & 2 & & & & & & & \\
\hline 517.00-616.99 & & 5 & 4 & 18 & 13 & 14 & 10 & 2 & & & & & & & \\
\hline $617.00-716.99$ & & 17 & 13 & 25 & 26 & 28 & 6 & 5 & 1 & 2 & & & & & \\
\hline $717.00-816.99$ & 1 & & 27 & 37 & 22 & 22 & 13 & 2 & 6 & 5 & & & & & \\
\hline $817.00-916.99$ & & 2 & 2 & 9 & 7 & 7 & 4 & 2 & & ? & 2 & 2 & & & \\
\hline $\begin{array}{c}\text {...with mature } \\
\text { embryos }\end{array}$ & & & & & & & & & & & & & & & \multirow{7}{*}{$\begin{array}{c}\text { Females with embryos }=168 \\
\text { Mean number of } \\
\text { embryos }=4.75\end{array}$} \\
\hline $417.00-516.99$ & & & & & & & & & & & & & & & \\
\hline 517.00-616.99 & & & 2 & 4 & & 3 & & & & & & & & & \\
\hline $617.00-716.99$ & 5 & 8 & 10 & 10 & 10 & 11 & 9 & 9 & & & & & & & \\
\hline $717.00-816.99$ & 2 & 7 & 15 & 10 & 11 & 11 & 1 & 4 & 2 & & & & & & \\
\hline 817.00-916.99 & & & & 5 & 4 & 7 & 3 & & & 2 & & & & & \\
\hline $917.00-1016.99$ & & & & & 3 & & & & & & & & & & \\
\hline $\begin{array}{l}P . \text { tergestina } \\
\text { body length... }\end{array}$ & \multicolumn{14}{|c|}{ Embryo number } & \\
\hline $\begin{array}{c}\text {...with premature } \\
\text { embryos }\end{array}$ & 1 & 2 & 3 & 4 & 5 & 6 & 7 & 8 & 9 & 1 & $0 \mid 1$ & & & $13 \mid 1$ & \\
\hline $392.00-491.99$ & & 4 & 8 & 9 & 7 & 15 & 5 & 6 & 6 & & & & & & \multirow{6}{*}{$\begin{array}{c}\text { Females with embryos }=572 \\
\text { Mean number of } \\
\text { embryos }=6.20\end{array}$} \\
\hline 492.00-591.99 & 4 & 15 & 17 & 32 & 32 & 37 & 23 & 12 & 19 & 5 & 2 & & & & \\
\hline $592.00-691.99$ & & 3 & 11 & 9 & 25 & 44 & 17 & 19 & 15 & 6 & 2 & 4 & & 3 & \\
\hline $692.00-791.99$ & & & 12 & 4 & 12 & 27 & 9 & 11 & 5 & s & & & & 3 & \\
\hline $792.00-891.99$ & & & 7 & 5 & 6 & 2 & 12 & 5 & 4 & 3 & 1 & & 5 & & \\
\hline 892.00-991.99 & & & & & & 4 & & & & & & & & & \\
\hline $\begin{array}{c}\text {...with mature } \\
\text { embryos }\end{array}$ & & & & & & & & & & & & & & & \\
\hline $392.00-491.99$ & & & & & & & & & & & & & & & \multirow{6}{*}{$\begin{array}{c}\text { Females with embryos }=160 \\
\text { Mean number of } \\
\text { embryos }=6.70\end{array}$} \\
\hline $492.00-591.99$ & & & & & 1 & 3 & & & & & & & & & \\
\hline $592.00-691.99$ & & & & 11 & 1 & 5 & 8 & 7 & & & & & & & \\
\hline $692.00-791.99$ & & & 7 & 9 & 12 & 8 & 16 & 12 & 5 & 2 & s & 7 & & & \\
\hline $792.00-891.99$ & & & & 4 & 9 & 3 & 5 & 3 & 6 & 2 & 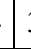 & 3 & & & \\
\hline 892.00-991.99 & & & & & & & & 5 & 2 & & & & & & \\
\hline
\end{tabular}




\section{REFERENCES}

AMADOR, E. S., 1982, Taxas de assoreamento da Baía de Guanabara. Variação por tempo e área. Ann. 32 Congr. Bras. Geol., 11: 1474-1482.

BAINBRIDGE, V., 1958, Some observations on Evadne nordmanni Loven. J. Mar. Biol. Ass. U.K., 37: 349-370.

BARTH, R., 1972, Inter-relação entre ambiente e reprodução de Evadne tergestina (Cladocera). Publ. Inst. Pesq. Mar., 67: $1-16$.

BERG, K., 1931, Studies on the genus Daphnia O.F. Müller with special reference to the mode of reproduction. Vidensk. Medd. Dansk. Naturh. Foren. Kbh, 92: 1-222.

CHENG, C. \& CHAO, W. C., 1982, Studies on the marine Cladocera of China II. Distribution. Acta Oceanol. Sinica, 4: 731-742 (in Chinese, with English abstract).

DELLA CROCE, N., 1974, Cladocera. Conseil International pour L'Exploration de la Mer-Zooplankton, 143: 1-4.

DELLA CROCE, N. \& BETTANIN, S., 1965, Sviluppo embrionale della forma partenogenetica de Penilia avirostris Dana. Cah. Biol. Mar., 6: 269-275.

FRONTIER, S., 1981, Cálculo del error en el recuento de organismos zooplanctónicos, pp. 169-188. In: D. Boltovskoy (ed.), Atlas del zooplancton del atlántico sudoccidental y métodos de trabajo con el zooplancton marino. Instituto Nacional de Investigación y Desarrollo Pesquero, Mar del Plata.

GIESKES, W. W. C., 1971, Ecology of the cladocera of the North Atlantic and the North Sea, 1960-1967. Neth. J. Sea Res., 5: 342-376.

GRIFFTHS, F. B., FLEMINGER, A., KIMOR, B. \& VANNUCCI, M., 1976, Shipboard and curating techniques, pp. 17-19. In: Zooplankton fixation and preservation - monographs on oceanographics methodology. UNESCO, Paris.

IBGE, 1977, Geografia do Brasil III - região Sudeste. Instituto Brasileiro de Geografia e Estatística, 89p.

MARCUS, N. H., 1996, Ecological and evolutionary significance of resting eggs in marine copepods: past, present, and future studies. Hydrobiologia, 320: 141-152.

MCEWEN, G. F., JOHNSON, M. W. \& FOLSOM, T. R., 1954, A statistical analysis of the performance of the Folsom plankton sample splitter band upon test observations. Arch. Met. Geophys. Bioklim. (Sec. A), 7: 502-527.
NOGUEIRA, C. R., BONECKER, A. C. T. \& BONECKER, S. L. C., 1988, Zooplâncton da Baía de Guanabara (RJ-Brasil) composição específica e variações espaço-temporais, pp. 150-156. In: F. P. Brandini (ed.), Memórias do III Encontro Brasileiro de Plâncton, Caiobá, Paraná.

ONBÉ, T., 1974, Studies on the ecology of marine cladocerans. J. Fac. Fish. Anim. Husb. Hiroshima Univ., 13: 83-179 (in Japanese, with English abstract).

ONBÉ, T., 1977, The biology of marine cladocerans in warm temperate water, pp. 383-393. In: Proceedings of a Symposium on Warm Water Zooplankton. Special publication, UNESCO/ National Institute of Oceanography, Goa.

ONBÉ, T., 1978a, Life cycle of marine cladocerans. Bull. Plankton Soc. Jpn, 25: 41-54 (in Japanese, with English abstract).

ONBÉ, T., 1978b, Gamogenetic forms of Evadne tergestina Claus (Branchiopoda, Cladocera) of the Inland Sea of Japan. J. Fac. Fish. Anim. Husb. Hiroshima Univ., 17: 43-52.

ONBÉ, T., 1985, Seasonal fluctuations in the abundance of populations of marine cladocerans and their resting eggs in the Inland Sea of Japan. Mar. Biol., 87: 83-88.

PLATT, T. \& YAMAMURA, N., 1986, Prenatal mortality in a marine cladoceran, Evadne nordmanni. Mar. Ecol. Prog. Ser., 29: 127-139.

RAMIREZ, F. C., 1981, Cladocera, pp. 533-542. In: D. Boltovskoy (ed.), Atlas del zooplancton del Atlántico Sudoccidental y métodos de trabajo con el zooplancton marino. Instituto Nacional de Investigación y Desarrollo Pesquero, Mar del Plata.

RAMIREZ, F. C. \& PEREZ SEIJAS, G. M., 1985, New data on the ecological distribution of cladocerans and first local observations on reproduction of Evadne nordmanni and Podon intermedius (Crustacea, Cladocera) in Argentine Sea waters. Physis A, 43: 131-143.

ROCHA, C. E. F., 1982, Distribution of the marine cladocerans (Crustacea, Branchiopoda) off Santos, Brazil. Bol. Zool. Univ. S. Paulo, 7: 155-169.

SPECCHI, M., DOLLINAR, L. \& FONDA-UMANI, S., 1974, I Cladoceri del genere Evadne nel Golfo di Trieste. Notizie sul ciclo biologico di Evadne nordmanni, Evadne tergestina ed Evadne spinifera. Boll. Pesca Piscic. Idrobiol., 29: 107122. 